\title{
Texiscape.
}

\section{ANATOMY AND PHYSIOLOGY.}

152. Nervenzellen UND GRAUE Substanz (Nerve Cells and Gray Matter). Nissl (Münchener medicinische Wochenschrift, 1898, Nos. 31, 32, and 33.)

Alluding to his most recent experiments on the action of various poisons upon the nerve cells, and pointing out the various sources of error, the author takes as his starting point a disease of the cells of the human cortex, which he says he has best studied, and which he calls the "acute cell disease." In this all the cells of the cortex are affected, the whole cell body suffering, and the changes in them are entirely characteristic. These changes show that the unstained part of the cell consists not only of fibrillary substance, but also of something else. This acute cell disease is found in acute cases of paresis, in various psychoses, and also in patients dead of other diseases, who prior to $d \in$ ath have been delirious or somnolent.

Recent investigations all seem to show that the functionally active part of the cell is that left unstained in Nissl's method, and through the masterly researches of Apathy, and of Bethe, this has acquired the greatest importance. "The quintessence of the newer investigations consists in the fact that the nerrous tissue can no longer be considered as a community of countless nerve cell individuals, which posuess, so to say, some a greater, others a smaller, radius of action, but we must regard it as composed of nerve cells, and a specific nervous substance, namely, the fibrillary substance."

This is a living substance, a spccially differentiated nerve cell protoplasm in its highest development, and appears to be directly concerned ii: carrying on nervous functions. The conducting element is undoubtedly the primitive fibrils. The neuron conception, the author thinks, is hardly reconcilable with the recent advances in knowledge of the histopathology of the nervous system, since it was originally based upon the Golgi method, and we do not know to-day just to what tissues the blackening by this is limited. He next proceeds to discuss the gray matter in its histological constitution, and points out that the usual view, that it is a part of the nervous system, in which nerve cells and neuroglia cells and fibers predominate, does not explain all its peculiarities, since in some parts of the gray matter cells are very few in number, while again, the white matter in certain regions contains a good many cells. The criterion for the distinction between gray and white matter he finds not in the relative abundance of nerve cells and nerve fibers, but in the presence or absence between the cells, fibers and vessels, of a peculiar molecular substance which gives the gray color. This substance, he thinks, must be regarded as an active factor in the mechanism of the nervous system, and probably is made up largely of the fibrillary substance already mentioned, though positive proof of this has not yet been secured. Certain it is, that in the functionally highest parts of the nervous system there is, along with the nerve cells, something which is made up neither of neuroglia nor of the sum of the processes of nerve cells. To show this the author gives pictures of sections taken from as near as possible corresponding portions of the 
cortex in the posterior part of the motor region, in man, the dog and the mole. In these it appears that in the second and third Meynert's layers there is a difference in the proportion of cells and intercellular substance, the former being less, the latter being more abundant, the higher in the scale of intelligence we rise. The author has always claimed, in opposition to many authorities, that there is a difference in structure in the nerve cells from functionally different portions of the nervous system. The specific nervous substance is in very close relationship with the nerve cell. It is found, first, in the cell body-and here, according to Bethe, there are to be distinguished central fibrils and peripheral fibrils; second, it surrounds the cells with their dendrites as "a true closed and rather close-meshed net." (Held.) The dendrites seem to be designed for bringing cells into extensive relations with the specific nervous substance, and, considering the arrangement of the axis cylinder processes, the nerve cells scem to be "collection stations" for the filbrillary substance, "in which the fibrils undergo a rearrangement in behalf of conduction into other processes, and forming the axis cylinder process." The axis cylinders, coning together, form important nerve tracts. It must not be thought, however, that the nerve cell plays but a subordinate rôle in the work of the central organ, for while the researches of Bethe show that in invertebrates reflexes can be excited without the intervention of a cell these reflexes are feeble, and are soon exhausted.

In no case of psychical disturbance has the author failed to find a number of the cortical nerve cells diseased. The nerve cell is sterile, as far as reproducing other nerve cells is concerned, but is able to reproduce the fibrillary substance in large quantity. How is not known. The author next considers the portion of the cell staining with methylene bluc, the tigroid or Nissl bodies. This is improperly called, since it is not homogencous. but is composed of several substances which react differently in different cells. The nucleus next engages his attention; he shows that its structure is complicated and varies in different cells, and that it is composed of several differently reacting substances. The increase of capability, as we advance from the lower to the higher order of animals, is due to the ever greater division of labor among the individual cells, through their greater specialization. By the nerve cells, the nutritive functions of the gray matter and fibril tracts are regulated, and a condition of tension ready to set at liberty nervous impulses under the slightest irritation is produced. The position of the nerve cell as a collecting station has already been alluded to, and the question is raised if there are not fibrils which, running in the collaterals, enter the main axis cylinder without touching the nerve cell, a condition which Bethe has shown to exist in the case of the dendritic fibrils. However, even assuming this to be the case, the nerve cell does not lose its importance, since its intimate connection with the specific nervous substance cannot be denied. Both arise from the same basis. and their separation into nerve cell and nerve substance is interesting chiefly as an example of division of labor.

Aillen.

153. Apuntes para el estudio estructural DE la corteza visuar. DEL CEREBRo HUMANo (Observations on the Structure of the Visual Cortical Area in Man). S. Ramon y Cajal (Revista IbercAmericana de Ciencias medicas, March, 1899).

Cajal has given an extensive study with a complete literature on the structure of the cuneus and the cortex bordering on the calcarine fissure. This is but onc of the author's many morphological studies on the cortex of the human brain. From without inward in the region of the cuncus he distinguishes eight different zones, as follows: I. The 